\title{
Tracking the quality premium of certified coffee: Evidence
}

\author{
from Ethiopia
}

\begin{abstract}
Certification of Voluntary Sustainability Standards (VSS) is rapidly increasing in global value chains. While consumers, mostly in developed countries, are willing to pay significant premiums for the certification of such standards, it is not well understood how effectively these incentives are transmitted to producing countries. We study VSS - more in particular Fair Trade and Organic certification - in Ethiopia's coffee sector, the country's most important export commodity, using a unique census of transaction data at the export level and large-scale data at the production level. We find that transmission of export quality premiums to coffee producers is limited, with only less than one-third of this premium being passed on, and we find limited evidence of effects due to communal investments. Moreover, as quality premiums are small and average production levels in these settings are low, we estimate that these premiums would only lead to an increased income for coffee farmers of 22 USD per year even with a perfect transmission scenario, and therefore would have little impact on the welfare of the average coffee farmer. Given that the VSS studied are characterized by the highest premiums among VSS schemes, it can be assumed that even lower benefits from other VSS certification schemes trickle down to producers.
\end{abstract}




\section{INTRODUCTION}

There is a growing emphasis in international markets on Voluntary Sustainability Standards (VSS) practices, seemingly as a response to enhanced global social and environmental pressure (Giovannucci and Ponte, 2005; Swinnen, 2007; Henson and Reardon, 2005). By guaranteeing the product origin, fair prices to producers, adherence to ethical standards in production and processing, environmental sustainability, and safety and quality safeguards - as shown through a certificate of VSS -, international buyers and consumers are often willing to pay extra for a product. Conversely, adhering to those new requirements can be expensive with costs coming from several sources. For example, VSS certified organizations are required to put in place environmental, labor, and safety standards and also put documentation systems in place to monitor the production process. The certifying organization's charges can also be substantial (de Janvry et al. 2014). This often raises questions about who actually benefits from the imposition of these standards and if these VSS achieve their objectives (Haight 2011). ${ }^{1}$

The coffee sector has led the field in applying different VSS (Potts et al. 2014). In this global sector - one of the most important traded agricultural commodities in the world - it is estimated that 18 percent of coffee production was sold as VSS certified in 2015, up from 4 percent in 2005 (Giovannucci et al. 2014). This share is expected to reach significantly higher levels in the near future (Pierrot et al. 2011; Giovannucci et al. 2014; Potts et al. 2014). ${ }^{2}$ Despite the increasing global demand for VSS and the large share of coffee producers that supply their products under these schemes, there are relatively few studies that examine the impacts of these arrangements on coffee producers or on the distribution of the quality premium along the coffee supply chain. Most available studies have focused on identifying the impacts on the producer level. The findings are mostly mixed, with some exposing positive impacts (e.g. Ruben and Fort 2012; Wollni and Zeller 2007; Weber 2011; Barham and Weber 2012; Dragusanu et al. 2014; Rueda and Lambin 2012; 2013; Chiputwa et al. 2015; Bacon, 2005), while others find little effect

\footnotetext{
${ }^{1}$ In the literature, there are opposing views on the impact of standards on smallholders in developing countries. On the one hand, certification has been found to be beneficial and smallholders are able to thrive under the imposition of more stringent standards (e.g. Minten et al. 2009; Kersting and Wollni 2012; Wang et al. 2009). On the other hand, there are findings that the impact of standards is minimal or negative (Jena et al. 2014; Dragusanu and Nunn 2014). Reardon et al. (2009) even find that standards can lead to the exclusion of smallholders in these agricultural value chains, especially when firms have procurement options.

${ }^{2}$ For example, the Sustainable Trade Initiative has an agreement with major roasters towards increasing global sustainable coffee sales to 25 percent in 2016. See http://www.idhsustainabletrade.com/koffie-news
} 
(e.g. Jena et al. 2012; Cramer et al. 2014; Haight 2011; de Janvry et al. 2014; Dragusanu and Nunn 2014; Stellmacher and Grote 2010; Valkila and Nygren 2009; Valkila, Haaparanta, and Niemi, 2010; Beuchelt and Zeller 2011; Elder et al., 2012). In Africa especially, there are few studies on this, possibly because of the lower uptake of VSS than in the rest of the world (CTA 2013).

We look at this issue in the case of the coffee sector of Ethiopia, its most important export product which accounts for about a quarter of its foreign exchange earnings. ${ }^{3}$ Our contribution to the literature is two-fold. First, this is the first study that examines how the quality premium of VSS certification - in particular Fair Trade and Organic certification - is distributed between export and production levels in producing countries. We study the use of the quality premium at two levels. We first look at the transmission of the quality premium from export levels to producers. Then, as some of the funds obtained from the quality premium of VSS certification provide benefits to coffee farmers in other ways than by higher prices because they are e.g. invested in communal assets and in agricultural extension, we test to what extent VSS certification is associated with other intended changes. Second, to examine these questions, we use exceptionally rich datasets, i.e. a census of coffee transactions over a nine-year period, a time-series of coffee producer prices over an eight-year period, and a comprehensive representative survey of 1,600 coffee producers. Moreover, we combine qualitative and quantitative information from these surveys as well as insights from key informant interviews. This comprehensive approach provides confidence in our findings for Ethiopia, the biggest coffee producing country in Africa, and beyond.

We find that there are statistically significant quality premiums attached to VSS certified coffee at the export level. However, there are only small price premiums at the producer level - producers received less than one-third of the quality premium for VSS certification realized by coffee exporters. ${ }^{4}$ The gap in effective transmission is seemingly explained by important overhead and certification costs and by investments in communal services that might

\footnotetext{
${ }^{3}$ In Ethiopia, there are a number of studies that have examined issues of coffee certification. There are two major drawbacks to previous studies. First, several of these studies were qualitative (e.g. Stellmacher \& Grote 2011) and fail to illustrate quantitative impacts. Second, when surveys were fielded, they were limited spatially or only focused on one type of certification (e.g. Kodama 2009; Jena et al. 2012; and Cramer et al. 2014).

${ }^{4}$ These results are consistent with analysis from other countries which show that typically 10 percent of premium paid for VSS certified coffee at the retail level in Western countries goes to the producer (e.g. Valkila et al. 2010, Mendoza and Bastiaensen, 2003; Kilian et al., 2006; Johannessen and Wilhite, 2010) and that these premiums mainly empower roasters and retailers. On the other hand, Langen and Adenauer (2013) maintain that 50 percent from the
} 
not directly improve the prices received by individual producers. However, we also do not find large-scale improvements in the stated objectives linked with these communal investments. Compliance costs at the cooperative and household level are often found to be high. Moreover, we find that, even if the transmission of premiums were more efficient, it would likely result in limited impact on the welfare of poor farmers. If an average Ethiopian coffee farmer, who annually sells the equivalent of 400 kilograms of red cherries, were to market all his or her red cherries as VSS certified, with current VSS premium transmission rates, the farmer's annual income would increase by 6.7 USD compared to the non-certified cooperative farmer (assuming both types of farmers sell all coffee to the cooperative). Even in the case of a perfect transmission, the annual income of the average certified coffee farmer would only increase by 22 USD compared to a non-certified cooperative farmer. ${ }^{5}$ These premiums from VSS certification are therefore unlikely to significantly contribute to improving the welfare of coffee producers. The findings of our study therefore raise doubts on some of the fundamental propositions of VSS, and Fair Trade in particular.

The structure of the paper is as follows. First, we provide some background information on VSS in the coffee sector. Section 3 presents a conceptual framework and empirical methodology. In Section 4, we describe the data used for this study. Empirical results on the quality premiums and its transmission between different layers in the value chain are presented in Section 5. In Section 6, we test to what extent VSS certification achieves its intended objectives. We then finish with a discussion of the findings.

\section{VOLUNTARY SUSTAINABILITY STANDARDS (VSS) IN COFFEE}

Concerns for producers' income combined with those for social injustice and environmental destruction have led to a global movement for sustainability standards (Giovannucci et al. 2014; Pierrot et al. 2011). The demand for VSS certification for coffee arguably took off globally in the early part of the 2000s when the international price of coffee declined dramatically, creating hardships for many poor smallholder coffee producing households. In 2005,

premiums goes to the producers in four Latin American countries. However, most of this analysis suffers from lack of representative data at the different levels of the value chain in producing exporting countries. This is important given the large heterogeneity that is often found in these settings.

${ }^{5}$ The certified cooperative allows for higher quantities to be sold to the cooperative compared to non-certified cooperatives. However, even taking this into consideration does not change this overall picture much. We thank a reviewer for pointing this out. 
it was estimated that 4 percent of all coffee was VSS certified. This has grown quickly since then and it is estimated that the share sold as VSS certified has now reached almost 20 percent of the global trade in coffee (Giovannucci et al. 2014). The main sustainability standards include Fair Trade, Organic, Rainforest Alliance, Utz Certified, and 4C Code of Conduct (Potts et al. 2014).

The Fair Trade movement has its origin in initiatives by charities in the United States and Europe, usually linked to churches, that created "alternative trade" channels for, mostly non-agricultural, products of impoverished people (Jaffee, 2014; Bacon, 2010). A milestone in the Fair Trade movement was the start of the Max Havelaar coffee by a church-based NGO in the Netherlands in response to low coffee prices. The Max Havelaar foundation licensed the use of the label to existing coffee roasters and retailers who agreed to comply with its criteria of fairness in trade, giving impetus to the start-up of the Fair Trade Labeling Organization (FLO) in 1997 (Jaffee, 2014). The vision of the initiative was to ensure that producers would realize sufficient incomes by assuring minimum prices and by guaranteeing social standards. ${ }^{6}$

Organic certification, a second VSS, ensures that the coffee has been produced under organic standards. It emphasizes systems that promote and enhance agro-ecosystem health, including biodiversity, biological cycles, and soil biological activity. For a lot of coffee to obtain an organic certificate, it is required that no inorganic inputs have been used on the farm for two years prior to harvesting the crop. There is often double certification where Fair Trade and Organic certifications have been combined: Pierrot et al. (2011) estimate that this combination made up 42 percent of global Fair Trade coffee. Notably, these two VSS were the first to be implemented globally. ${ }^{7}$

A number of other more recently developed certification schemes are now also important globally, but less so in Ethiopia. Utz certification uses social and environmental criteria, promotes better business practices, and focuses on a tracking system to ensure that coffee producers implement good agronomic practices, which the industry

\footnotetext{
${ }^{6}$ Fair Trade's interventions for producers can basically be divided in two (see https://www.Fair Trade.net/products/coffee.html). First, a minimum floor price (the Fair Trade Minimum Price) is set for whenever the international price falls below a specific threshold. Second, a premium (the Fair Trade Premium) is put aside in a communal fund to be used towards capacity building and community development projects.

${ }^{7}$ Initially, Fair Trade certification could only be granted to groups of smallholders organized in producer organizations. However, this is no longer true for all product types. Fair Trade can now be achieved by both small producer organizations and larger commercial organizations that hire-in labor.
} 
then rewards (Potts et al. 2014). Rainforest Alliance certification aims to ensure sustainable livelihoods by transforming land-use, business practices, and consumer behavior (Potts et al. 2014). Independent certification by separate global certification organizations is required for these four major VSS. ${ }^{8}$ The $4 \mathrm{C}$ ("Common Code for Coffee Community") Association aims to establish a code of conduct for global coffee trade. In contrast with other VSS, the 4C initiative relies on self-assessment and a three-year verification cycle (Panhuysen and Pierrot 2014). Two other VSS initiatives belong specifically to private companies that have their own standards. CAFÉ (Coffee and Farmer Equity) Practices is a green coffee sourcing program developed by Starbucks in collaboration with Conservation International. Nespresso AAA guidelines have a similar set-up.

Figure 1 shows at the global level the importance of the different types of VSS, indicating production as well as sales estimates under each in 2013. Although it is one of the most recent initiatives in VSS in coffee trade, the 4C Association compliant coffee is by far the most important. While Organic and Fair Trade were traditionally the most adopted VSS in the global coffee sector, Rainforest Alliance and Utz Certified are growing much faster than Organic or Fair Trade, as they provide less challenging requirements in some areas and more business-friendly approaches (Giovannucci et al. 2014). Figure 1 also shows that a significant portion of coffee that is produced under VSS is not sold under that label. It was estimated in 2013 that 40 percent of the global coffee production was produced under one of these VSS, but that only 15 percent was actually sold using a VSS-certified label (Panhuysen and Pierrot 2014).

\footnotetext{
${ }^{8}$ It is to be noted that the costs of certification at the producer level are borne by these producers individually or by producer organizations.
} 


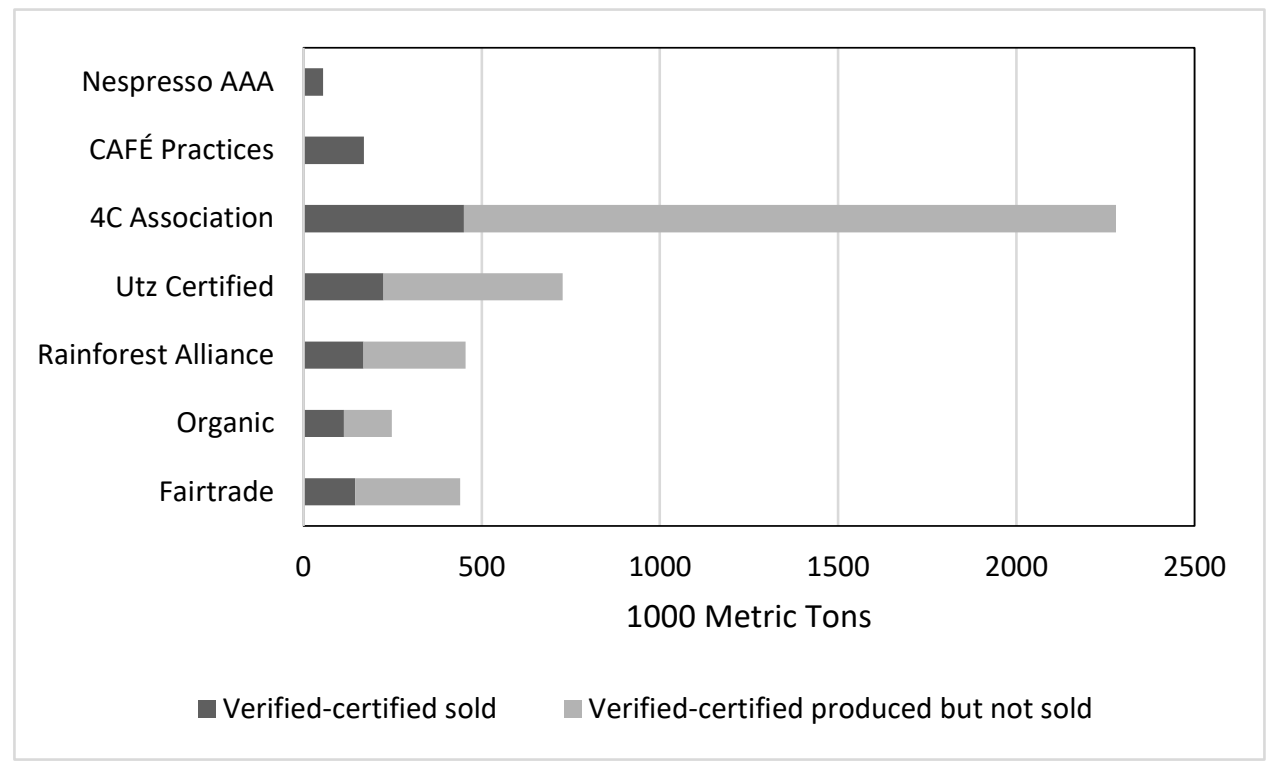

Source: Panhuysen and Pierrot (2014)

VSS certification of coffee is a relatively new phenomenon in Ethiopia. In 2000 , only one certifier in the country was accredited to issue these certificates. Since 2006, however, the country has attracted several international certifiers, including for Fair Trade, Organic, Utz, and Rainforest Alliance (Stellmacher and Grote 2011). A number of cooperatives and commercial farms have since obtained certification for their export coffee under different schemes. However, while there has been an increase in the last decade, the adoption of VSS certificates in Ethiopia has been significantly below world averages (Figure 2). It is estimated that VSS certified exported coffee from Ethiopia made up 2 percent of all Ethiopian coffee exported in 2005. This value rose to 5 percent by 2015. Most of the VSS certified coffee is exported by cooperatives, and the majority of coffee that is exported by cooperatives is VSS certified - over the period 2010-2013, VSS certified coffee varied between 72 and 83 percent of all exports by cooperatives. ${ }^{9}$ Some private firms also export VSS certified coffee, almost all organically certified.

\footnotetext{
${ }^{9}$ About one-third of the primary coffee cooperatives - which are subsequently organized into cooperative unions - in Ethiopia have VSS certification. Organic certification is the dominant VSS: 29 percent of all the primary coffee cooperatives are organically certified. The next most important VSS certification in Ethiopia is Fair Trade with 28 percent. The other two types of VSS certificates prevalent in Ethiopia, Rainforest Alliance and Utz Certified, are not yet widely adopted. Out of all the cooperatives, just 2 percent of cooperatives are certified with one or the other of these two VSS schemes. Double certification of Fair Trade and Organic is common, with 98 percent of Organic certified cooperatives also having Fair Trade certification, and similarly 80 percent of Fair Trade certified cooperatives also having Organic certification (Hoebink et al., 2014).
} 
However, their importance is relatively small in the total exports of VSS certified coffee from Ethiopia, i.e. 12 percent in 2013.

Figure 2-Evolution of Voluntary Sustainability Standards in the coffee sector, globally and in Ethiopia

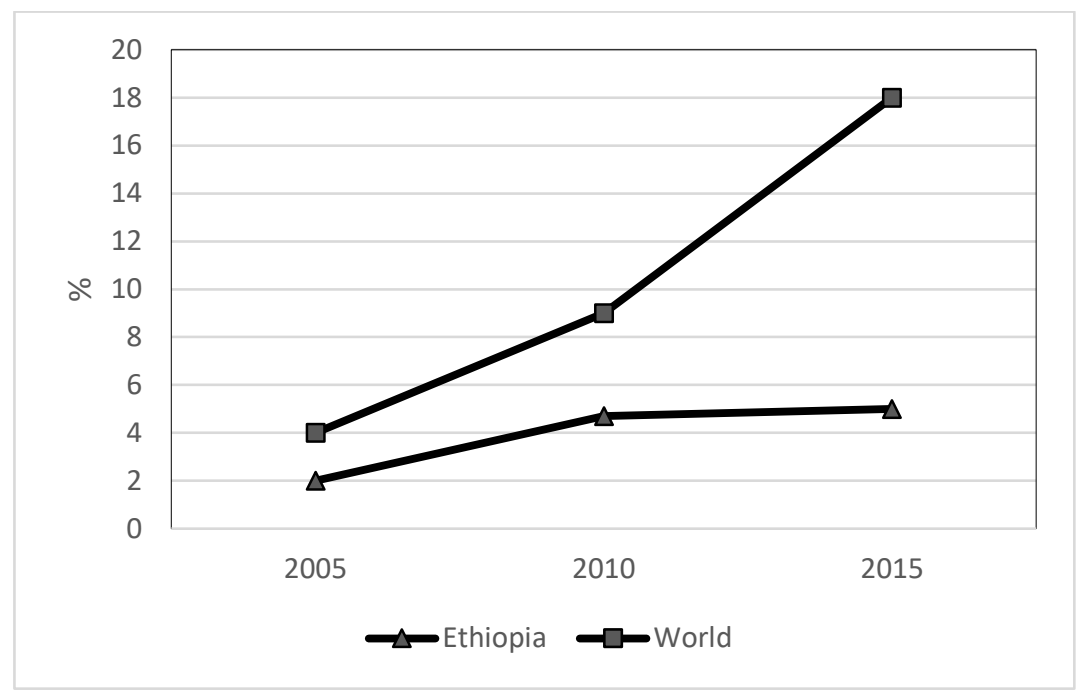

Source: Giovannucci et al. (2014) for world; Kodama (2009) and authors' estimates for Ethiopia.

\section{CONCEPTUAL FRAMEWORK AND EMPIRICAL METHODOLOGY}

To motivate our empirical analysis, we follow the theoretical model developed by Lancaster (1966). We consider a food product (or a group of food products) as a collection of characteristics or attributes. A food product $i$ can be described by a vector of attributes $x_{i}=\left\{x_{i}^{0}, x_{i}^{1}, \ldots x_{i}^{N}\right\}$ with $x_{i}^{k}$ the level of attribute $k$ in good $i$. Attributes are defined in such a way that consumers derive positive utility from them: $U=U\left(x^{0}, x^{1}, \ldots x^{N}\right)$ with $\partial U / \partial x^{k} \geq 0$. For reasons of simplicity, we assume that $U$ is measured in monetary equivalent. If two food products $i$ and $j$ differing only in attribute $k$ are offered in the market, their price difference will adjust to the point where consumers are indifferent between the two:

$$
\begin{aligned}
& U\left(x_{i}^{0}, \ldots, x_{i}^{k}, \ldots x_{i}^{N}\right)-p_{i}=U\left(x_{j}^{0}, \ldots, \ell_{j}^{k}, \ldots x_{j}^{N}\right)-p_{j} \\
& p_{i}-p_{j} \approx \frac{\partial U}{\partial x^{k}}\left(x_{i}^{k}-\ell_{j}^{k}\right)
\end{aligned}
$$


The price differential between the two food products can thus be regarded as the implicit price of attribute $k$. We assume agricultural producers have identical production possibility frontiers $G(x, I) \leqslant 0$, where $/$ is the vector of inputs required to produce a vector of attributes $x$. Positive values of $G$ correspond to inefficient input/output combinations.

The efficient allocation is obtained by solving a social planner problem of the form:

$$
\max _{\{x, l\}} U\left(x^{0}, \ldots, x^{N}\right)-\sum_{n=1}^{M} p_{n} l_{n}
$$

subject to: $G\left(x^{0}, \ldots, x^{N} ; l_{1}, \ldots l_{M}\right) \leq 0$

At the optimum, it follows that:

$$
\frac{d p}{d x^{k}}=\frac{\partial U}{\partial x^{k}}=p \frac{\partial G}{\partial x^{k}}
$$

This implies that, in an efficient equilibrium, the price premium associated with attribute $k$ is equal to the marginal utility of that attribute (expressed in monetary equivalent) and is equal to the marginal cost of producing the attribute.

If we assume the marginal utility and the implicit price for each characteristic to be constant, a hedonic price regression can be estimated where the food price is a function of the characteristics of the product, which are determined by the choice of a particular variety, or by the specific post-harvest technologies used. A simple model of the following form can then be estimated:

$$
p=\sum_{\mathrm{k}=0}^{\mathrm{N}} \beta_{\mathrm{k}} X^{k}+v
$$

where $p$ is the price of the product, $X^{k}$ is the level of the attribute $k, \beta_{k}$ the implicit price of attribute $k$, and $v$ a stochastic error term. We apply this conceptual framework to the issue that we study.

In particular, we estimate the impact of VSS certification on price formation at different levels in the value chain by the following estimation strategy: 


$$
p_{j t}^{m}=\beta_{0}+\beta_{1} * V S S_{j t}^{m}+\sum_{i} \beta_{2} * X_{i j t}^{m}+\sum_{j} \beta_{3} * \alpha_{j}^{m}+\sum_{t} \beta_{4} * \eta_{t}^{m}+v_{j t}
$$

where $p^{m}{ }_{j t}$ represents the coffee price of firm $j$ at time $t$ at level $m$ in the value chain, $V S S_{j t}$ is a binary variable equal to 1 in time $t$ when the buyer has a VSS certificate and 0 otherwise, $X_{i j t}$ is a vector of $i$ variables that affect price levels such as quality and origin of the coffee. $\alpha_{j}$ are buyer fixed effects, while $\eta_{t}$ are monthly fixed effects. The parameter that we are interested in is $\beta_{1}$, which captures the effect of a VSS for the buyer. The assumption for this to be a valid specification is common trends among VSS and non-VSS buyers and conditional independence between the price outcome variable and the VSS variable. This type of regression is run at two levels in the value chain, at the exporter and at the primary cooperative levels. Standard errors were clustered at the buyer level for all panel analysis and at the kebele (village) level for the farm survey.

\section{DATA}

To study voluntary sustainability standards, we rely on different unique large-scale datasets. The primary surveys were conducted by the authors as part of an initiative of the Ethiopia Strategy Support Program (ESSP), a joint program of the International Food Policy Research Institute (IFPRI) and the Ethiopian Development Research Institute (EDRI). First, a survey with 1,600 producers was fielded in February 2014. We focused on those zones that produced the most coffee in the country (Figure 3). To select the producers for the survey sample, the zones were stratified based on the coffee variety produced, as classified for export markets (Sidama, Jimma, Nekempte, Harar, Yirgacheffe). ${ }^{10} 320$ producers were interviewed in each stratum, for a total sample size of 1,600 producers

\footnotetext{
${ }^{10}$ Within each of these five strata, woredas (districts) were ranked by total production. Two woredas were randomly selected from the more productive half of woredas and two from the lower producing half of woredas. A list of all the kebeles from these selected woredas was obtained and their annual coffee production levels determined. Two kebeles were randomly selected from the more productive half of kebeles and two from the lower producing half of kebeles in these woredas. Finally, a list of all coffee-producing households in the selected kebeles was developed. These households were ranked from small to large coffee producers based on area cultivated in the year before the survey. We divided the producers into two groups, the less productive and the more productive. 20 coffee producers in each kebele were then selected: 10 from the less productive group of producers and 10 from the more productive ones. In total, 16 kebeles were chosen in each of the survey strata, from which 20 coffee producers were selected for the survey sample. In this analysis, only non-weighted results are presented (as the focus is on highlighting differences of certified versus non-certified cooperative farmers).
} 
across the five strata. ${ }^{11}$ The survey was carried out by 50 enumerators, divided in 10 teams (2 teams per coffee type; 5 enumerators per team). Each team took care of 2 woredas and 8 kebeles, i.e. $20^{\star} 8=160$ interviews. Overall supervision was assured by the authors of this article.

Figure 3-Major coffee producing zones in Ethiopia in 2014

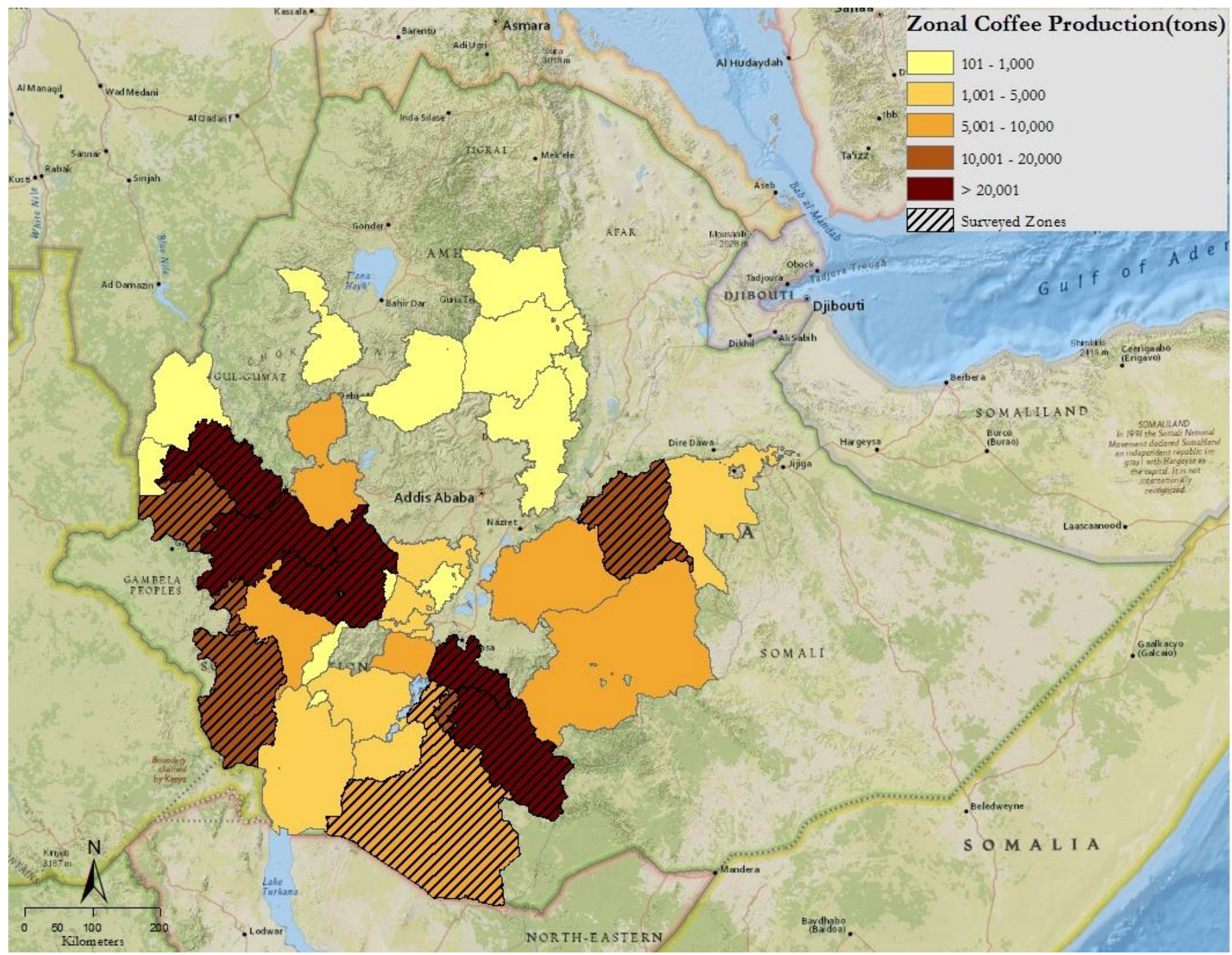

Source: Authors' mapping based on data from the Central Statistical Agency

${ }^{11}$ Plantation coffee grown on large commercial farms, private as well as state farms, were not part of the survey as they are relatively less important in coffee production in Ethiopia. 
Second, we collected information on prices offered to producers from primary cooperatives and private traders in major producing areas. Price data were collected from 12 major coffee producing zones in the country. In each zone, the three top producing woredas were selected and all primary cooperatives in each were visited. For each cooperative visited, we inquired if they had kept records on transaction prices, quantities, and total amounts paid out over the last 8 years and, if so, in what form these records were kept, i.e. receipts or a "record book". In the case where a transaction record book was maintained, we photocopied the book in the nearest town, and those data were subsequently entered into a database. Using this survey method, we were able to collect price information (for almost 150,000 transactions) from 89 cooperatives and 138 private traders. Moreover, a survey of cooperative unions was conducted in July 2014. Information was obtained on all certification types, the number of certified cooperatives in the union, start-up dates of certification, quantities exported under these certificates, and the premiums obtained from these certificates. All the cooperatives that were approached collaborated. ${ }^{12}$

Third, a database of coffee export transactions is maintained by the Ministry of Trade. This dataset was obtained for the period July 2006 to June 2014. An important aspect in coffee exports is quality. Quality assessments for exports are conducted by the Coffee Liquoring Unit (CLU) to ensure that the coffee meets export standards. A quality inspection sheet is prepared by the CLU and is attached to the lot to be exported..$^{13}$ These quality indicators, as well as others (such as washing, certification, and origin), are part of the coffee export transactions dataset. $^{14}$

\footnotetext{
${ }^{12}$ In the case of private traders, there was significant refusal. However, these data are not used in this analysis in a major way. These data were collected by the authors of this article, who traveled and interviewed these traders and cooperatives personally.

${ }^{13}$ The analysis of coffee quality by the CLU is based on two measures, the raw and physical inspection and the cup inspection. The raw and physical inspection contributes 40 percent of the final quality grade, while the cup inspection contributes 60 percent. However, moisture and screen analysis are the two requisites before grading any coffee. The moisture content should be less than 11.5 percent, while the size of the bean should be above screen size 14 for 85 percent of the bean sample. In the case of unwashed coffee, raw quality is determined based on defect count of the beans and on odor. In the case of washed coffee, the raw quality is based on an assessment of shape and make, color, and odor. Cup quality is assessed along four criteria - cup cleanliness, acidity, body, and flavor. Each characteristic counts equally for the cup quality value. The washed coffee export standards vary between grade 1 and 2, as well as under-grade (UG), while unwashed coffee is graded 3, 4, 5, or under-grade. Within the under-grade category, a further distinction is made for under-grade type 'inferior, but exportable' coffee, while the worst under-grade coffee is not exportable and is destined for domestic consumption.

${ }^{14}$ The Ethiopian Commodity Exchange (ECX) was established in 2008. A central trading system, warehouse delivery centers, product grade certification, clearing banks, an arbitration tribunal, a market information system linking rural sites, and remote electronic trading centers - all managed by the ECX were put in place to govern the local trade in coffee. A grading system was set up using as a basis for quality differentiation geographical origin, as was
} 
Finally, we obtained a list of private commercial coffee farms (with cultivated areas of 40 hectares and above) from the association of commercial coffee farms. This information was integrated into the dataset for analysis as well.

There are two caveats with the data that should be mentioned upfront. First, the empirical analysis relies on the estimation of average VSS effects on prices based on different samples. It could be argued that the estimated VSS coefficients are therefore not directly comparable over the different levels of the value chain. To address this potential problem, we focus our transmission analysis on the results of the most recent years (i.e. closest to the period that the household survey was fielded). Second, we are unable to separate out different VSS certifications (most importantly Fair Trade and Organic as other certifications were of minor importance in Ethiopia at the time of the surveys). As the large majority of the cooperatives had double certification and information on the type of VSS certification was not available in the collected transaction datasets, separating out effects of each type of VSS certification was unfortunately not possible with these data and this is therefore left for future research.

\section{QUALITY PREMIUMS FOR VSS CERTIFICATION}

\section{I. Export level}

Simply using observed prices of each exported lot expressed in US cents per lb., Figure 4 illustrates the size of the certification premium over the period 2006 to 2014 . The density function of VSS prices of certified coffee is distinctively to the right of non-certified coffee, indicating significant premiums at the export level. ${ }^{15}$ The average price difference amounts to 88 US cents per lb., statistically different when measured with a t-test $(\mathrm{t}=-78.61$;

done by the Coffee Liquoring Unit (CLU). While both use geographical origins as defining characteristic of quality, grades within those origins however differ.

${ }^{15}$ When Ethiopian coffees are compared to international markets, the New York futures $C$ market is usually used as a reference for comparison to cash coffee prices in Ethiopia. While there is a strong difference by quality, Ethiopian coffee prices have been shown to mostly track international Arabica coffee markets. Washed coffee from Ethiopia have been found to closely follow the New York International Coffee Organization (ICO) "cash milds" prices while unwashed coffees best track ICO cash "Brazilian naturals" prices (AGP-AMDE, 2015). 
$\operatorname{Pr}(|\mathrm{T}|>|\mathrm{t}|)=0.00)$. However, this simple price comparison masks other factors that might explain the VSS certification premiums. Mostly better quality coffee is used for VSS certification and to get at the additional value of certification on top of other variables, a multi-variate regression framework is required.

Figure 4- Export quality premiums for VSS certification of clean green coffee, 2006 to 2014

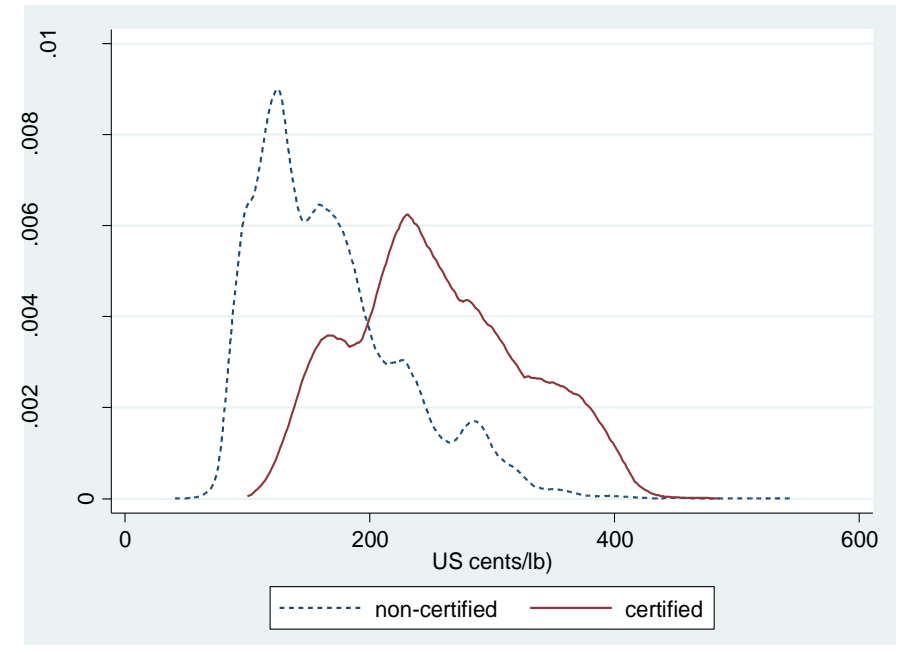

Source: Authors' calculations based on data from the Ministry of Trade

Following the methodology outlined in Section 3, we regress export prices of clean green beans in US cents per Ib. on VSS certification, quality indicators, the origin of the coffee, type of exporters, and monthly dummy variables (Table 1). ${ }^{16}$ In the first specification, we report the results of a pooled regression. The results show that coffee exported by cooperatives and private commercial farms obtains higher export prices compared to coffee exported by private exporters, even if we control for quality. In this case, certification raises the price of exports by 23 US cents per Ib. When we control for exporter fixed effects (Specification 2), we find that certification raises prices significantly by 16 US cents per Ib. When we run the exporter fixed effect model for cooperatives only (the third specification), VSS certification shows a premium of 13 US cents per lb., ceteris paribus. We are specifically

\footnotetext{
${ }^{16}$ The geographic origin of coffee is an important quality consideration, as it is strongly related to taste. In our analysis, we distinguish between Sidama, Jimma, Wollega (Nekempt), Yirgacheffe, Limu, Harar, and other coffees. Kufa (2012) associates tastes and regions as follows: spicy for Sidama, fruity for Wollega (Nekempt), floral for Yirgacheffe, winy for Limu and Jimma, and mocha for Harar. As shown in Table 1, coffee originating from Yirgacheffe and Harar coffee are sold, ceteris paribus, at higher prices than the Sidama coffee. In contrast, coffee produced in Wollega or Nekemte and Jimma are valued less than the coffee originating from Sidama. Studying the link of these premiums to production costs would be an interesting exercise but is beyond the scope of this study.
} 
interested in the premiums applied in recent years. We therefore restrict the sample to the years 2013 and 2014 . In those specifications, we find that VSS certification raises coffee prices by 11 and 15 US cents per lb. (as shown by the size of the coefficients for the VSS certification dummy variable) in a specification where all exporters are included (Specification 4) or where the sample is restricted to cooperatives only (Specification 5), respectively. The evidence suggests that there are statistically significant but small premiums of about 7 percent of the export price for coffee for VSS certification at the export level, slightly higher than those found in other studies for similar periods (de Janvry et al. 2014). 
Table I-Associates of coffee prices (US cents per lb.) at the export level, 2006 to 2014

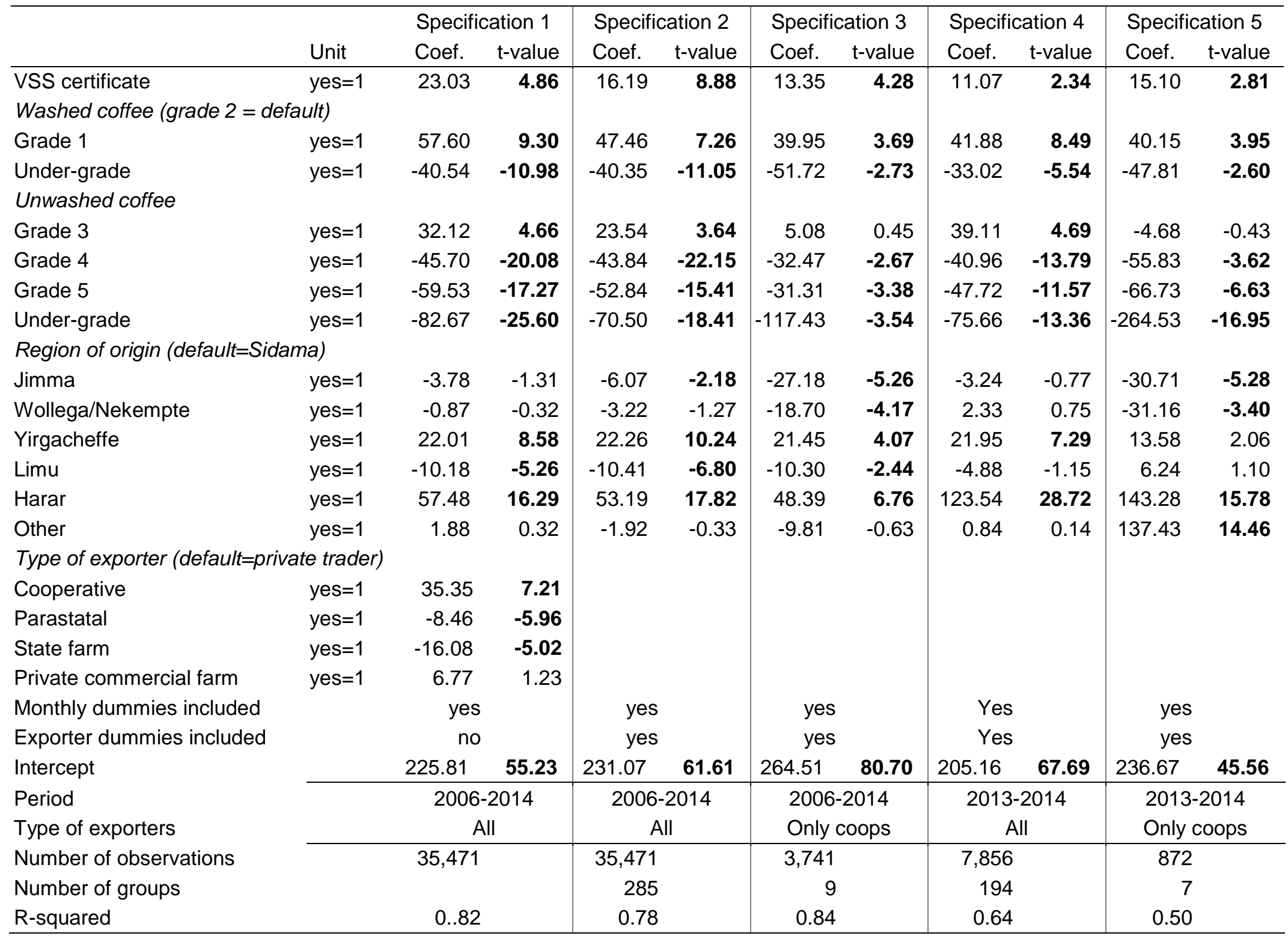

Source: Authors' calculations based on data from the Ministry of Trade

Note: Standard errors clustered at the exporter level; t-values in bold are significant at the 5 percent level. 


\subsection{Producer level}

We first present qualitative information from the 2014 coffee producer survey on farmer access to cooperatives and their price perceptions. Almost 40 percent of farmers in our survey had the option to sell to cooperatives (Table 2). Half of the farmers that had the option to sell to cooperatives sold to them. There is a significant difference in those with access to certified or non-certified cooperatives. Those that had the option to sell to certified cooperatives are much more likely to proceed with a sale to them than those that had access to a non-certified cooperative. Table 2 shows that cooperatives mostly focus on the procurement of red cherries, that are later processed as washed coffee. Farmers were further asked about the prices offered by cooperatives compared to other buyers. Some 43 percent of farmers believe that prices are higher while 28 percent and 22 percent think they are lower or the same, respectively.

Table 2-Access to cooperatives and price perceptions

\begin{tabular}{lcrrrr}
\hline & & \multicolumn{3}{c}{ Cooperatives } \\
& Unit & $\begin{array}{c}\text { Observa- } \\
\text { tions }\end{array}$ & $\begin{array}{c}\text { Non- } \\
\text { certified }\end{array}$ & $\begin{array}{c}\text { Certi- } \\
\text { fied }\end{array}$ & \multicolumn{1}{c}{ All } \\
\hline Farmer stated that they had option to sell to a cooperative & $\%$ & 1,598 & 21.2 & 18.2 & 39.4 \\
Share of farmers that sold red cherries to cooperatives & $\%$ & 1,598 & 2.4 & 14.6 & 17.0 \\
Share of farmers that sold dry cherries to cooperatives & $\%$ & 1,598 & 2.4 & 0.4 & 2.8 \\
Share of farmers that sold coffee to cooperatives & $\%$ & 1,598 & 4.7 & 14.6 & 19.3 \\
For those having option to sell to cooperatives & & & & & \\
Cooperatives buy: & & & & & \\
"Red cherries only" & $\%$ yes & 394 & 30.1 & 90.0 & 62.3 \\
"Dried cherries only" & $\%$ yes & 144 & 48.0 & 1.2 & 22.3 \\
"Both red and dried cherries" & $\%$ yes & 94 & 21.9 & 8.9 & 14.9 \\
Total & $\%$ yes & 632 & 100.0 & 100.0 & 100.0 \\
Cooperatives' prices for red cherries are: & & & & & \\
"Higher" & $\%$ yes & 210 & 35.4 & 46.6 & 43.2 \\
"Lower" & $\%$ yes & 137 & 3.4 & 38.9 & 28.2 \\
"The same" & $\%$ yes & 106 & 44.9 & 11.8 & 21.8 \\
"I do not know" & $\%$ yes & 33 & 16.3 & 2.6 & 6.8 \\
Total & $\%$ yes & 486 & 100.0 & 100.0 & 100.0 \\
\hline
\end{tabular}

Source: Authors' calculations based on ESSP's coffee producer survey 2014

To analyze effective quality premiums of VSS certification at the producer level, we use a time series of producer prices over an eight-year period from 2005 to 2012 that was collected from cooperatives and private traders. For each cooperative, information was obtained on the exact time that VSS certification was obtained. As most certified buyers focus on red cherries, we mostly use prices of those cherries as our dependent variable, converted to US cents per Ib. The results of different specifications are presented in Table 3. We first run a pooled regression 
where we regress the price of cherries on a VSS certification dummy variable, the bean form, type of buyer, an origin variable, and monthly dummies. As expected given their lower conversion ratio to exportable clean green beans, red cherries get significantly lower prices per kg compared to dried cherries and coffee beans. As found at the export level, we find higher prices for producers in Harar and Yirgacheffe compared to Sidama, and significantly lower ones for Jimma and Nekempte, indicating that these origin premiums at the export level are transmitted to producers. In this specification, we find that certification raises producer prices by 0.94 US cents per Ib. In a second specification, we only focus on red cherries. In this case certification raises prices by 1.56 US cents per Ib. In a third specification, we include fixed effects for buyers. In this model, we find that VSS certificates do not raise the producer price. This result is robust to a specification where we only include cooperatives (specification 4) and where we focus only on the most recent period (Specification 5). This evidence suggests that VSS certification did not lead to higher producer prices over the period considered. 
Table 3-Associates of prices of red cherries (in US cents per lb.) at the producer level, 2005 to 2012

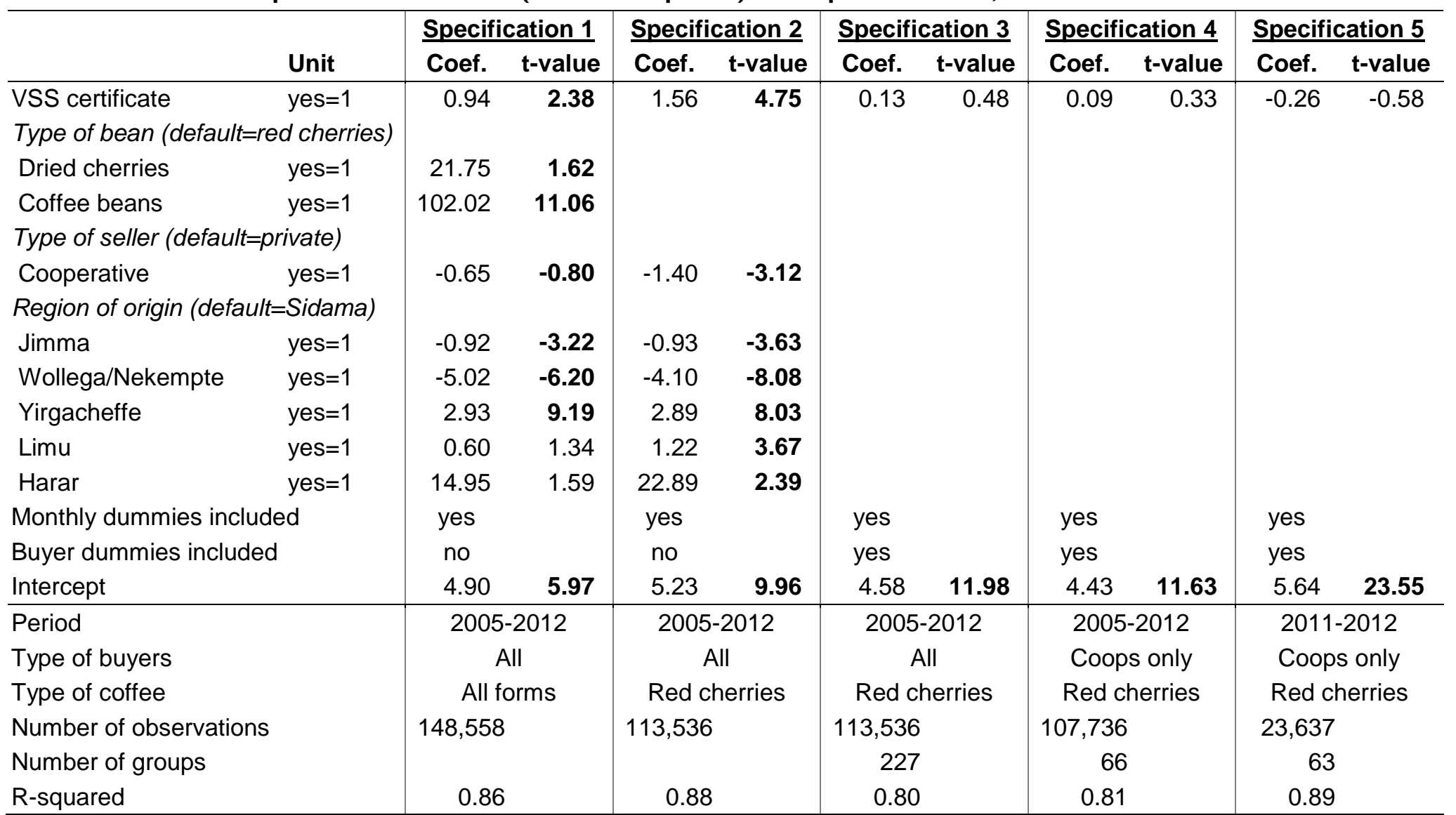

Source: Authors' calculations based on producer prices collected from primary cooperatives and private traders

Note: Standard errors clustered at the buyer level; $t$-values in bold are significant at the 5 percent level. 
One issue with the estimation of premium transmission in the method above might be that cooperatives pay a quality premium only after they have secured a buyer for the lot and have been paid. Some cooperatives also pay dividends. Analysis of prices recorded at the time of the initial transaction might therefore potentially underestimate the benefits of VSS certification. It is also to be noted that in the case of Fair Trade, cooperatives might invest in the social premiums collectively. We discuss this in detail in Section 5.3. While information on second payments and dividends was not in the record books, questions were asked on the incidence and level of these two payments during the farm survey of 2014. For those farmers that sold to cooperatives, 44 percent and 23 percent stated that they received second payments - an additional premium per kg sold - and dividends, respectively, in the 12 months prior to the survey (Table 4). Certified cooperatives are much more likely to have paid out second payments and dividends to farmers. 55 percent of the farmers who sold to certified cooperatives reported to have received a second payment and 27 percent of them received a dividend. Overall, 66 percent of the farmers that sold to certified cooperatives received an additional payment after the transaction. In the case that a second payment or a dividend was paid, a follow-up question relating to the exact amount was asked. On average, the second payment was $0.9 \mathrm{Birr} / \mathrm{kg}$, equivalent to an extra $0.14 \mathrm{US}$ cents per $\mathrm{lb}$. We also recorded the amounts of dividends that were paid. The median dividend paid out was 240 Birr per receiving household. These responses suggest that coffee incomes received from cooperatives have increased through second payments or dividends, and more so for certified farmers.

Table 4-Coffee sales to cooperatives, dividends and second payments

\begin{tabular}{lccccc}
\hline & & \multicolumn{4}{c}{ Cooperatives } \\
\cline { 5 - 6 } & Unit & $\begin{array}{c}\text { Obser- } \\
\text { vations }\end{array}$ & $\begin{array}{c}\text { Non- } \\
\text { certified }\end{array}$ & $\begin{array}{c}\text { Certi- } \\
\text { fied }\end{array}$ & All \\
\hline If farmer sold to cooperative: & & & & & \\
Share of red cherries sold to cooperatives & $\%$ & 272 & 80.6 & 92.0 & 90.4 \\
Share of dried cherries sold to cooperatives & $\%$ & 44 & 77.7 & 85.0 & 78.6 \\
Share of farmers that received a second payment & $\%$ & 307 & 8.1 & 55.4 & 44.0 \\
If received, amount (mean) & Birr/kg & 135 & 1.05 & 0.89 & 0.89 \\
If received, amount (median) & Birr/kg & 135 & 0.90 & 0.80 & 0.90 \\
Share of farmers that received a dividend & $\%$ & 308 & 10.7 & 27.0 & 23.0 \\
If received, amount (mean) & Birr & 62 & 1,697 & 294 & 475 \\
If received, amount (median) & Birr & 62 & 885 & 217 & 240 \\
Share of farmers that received a second payment or dividend & $\%$ & 307 & 13.5 & 66.1 & 53.4 \\
\hline
\end{tabular}

Source: Authors' calculations based on ESSP's coffee producer survey 2014 
To understand to what extent the second payments and dividends are raising producer prices paid to certified producers compared to non-certified ones, we rely on the reported prices for every coffee transaction at the household level during the year 2013. ${ }^{17}$ This information was collected during the farm survey. ${ }^{18}$ We analyze three types of producer prices from these transactions - the price that was paid immediately after the transaction, the price incorporating the second payment, and the price incorporating all payments (where dividends were converted to benefits per kg sold). Figure 5 shows the distribution of the price incorporating all payments for red cherries by market channel. ${ }^{19}$ The graph illustrates that certified cooperatives offer higher prices than non-certified ones and that cooperatives offer in general a higher price than other buyers. However, the graph also shows that the differences in the density functions are rather small. ${ }^{20}$

\footnotetext{
17 It is common in some countries that farmers borrow from traders, exporters or cooperatives to pay for input expenses or for harvesting. The reported output prices could then possibly not reflect the net price that the farmers received. It is to be noted that we instructed enumerators to record the full price but there is still the possibility that farmers did not understood. In the transaction section, a question was asked if the farmer received input advances from the particular buyer in that transaction. In 1.5 percent (red cherries) and 2.4 percent (dried cherries) of the transactions, such an interlinked transaction was reported during the survey. It seems that interlinked transactions are therefore less prevalent than in other settings - possibly because less improved inputs are used, farms are smaller, and hiring in labor is less relied upon - and the likelihood of mismeasurement of the price because of this interlinkage is therefore low.

${ }^{18}$ Export prices from Ethiopia in 2013 were on average just above 150 US cents per lb., coming down from 250 US cents per lb. in $2011 / 12$. While prices were in 2013 significantly lower than a couple of years earlier, they were still significantly above the prices offered during the "coffee crisis" years in the beginning of the century (in 2002 real coffee prices on world markets reached their lowest point for a century) (Eakin et al., 2016). It is important to note that this variation in international prices might have implications on the relative share of the quality premium for VSS certified coffee in the total price offered.

${ }^{19}$ We focus on red cherries as VSS certification almost exclusively deals with these.

${ }^{20}$ The average price differences of sales to certified cooperatives versus sales to non-cooperatives and non-certified cooperatives are 1.76 and 1.13 US cents per lb. respectively (both significant with a t-test, i.e. $\mathrm{t}=7.99$ and $\mathrm{t}=2.96$ respectively). There is no significant difference between sales to non-certified cooperatives and those to non-cooperatives (difference of 0.63 US cents per lb. with a t-value of -1.26 and a $\operatorname{Pr}(|\mathrm{T}|>|\mathrm{t}|)=0.21$.
} 
Figure 5-Producer quality premiums for VSS certification of red cherries, based on combined prices of first and second payments and dividends, by market outlet, 2013

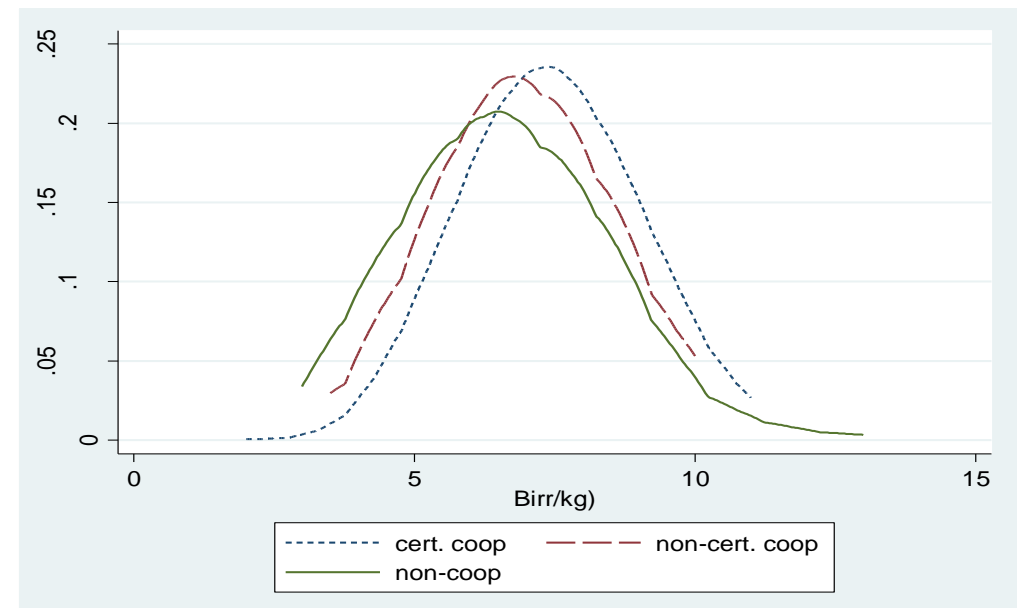

Source: Authors' calculations based on ESSP's coffee producer survey 2014

In Figure 4, we do not control for other explanatory variables of price formation. Following the model of Section 3, we therefore regress prices for red cherries on dummy variables that reflect the type of buyer (including sales to a certified and non-certified cooperative), perceived quality of the red cherries, place of sales, month of sales, and woreda dummies. For the dependent variable, we use three price measures: $1 /$ the first payment; $2 /$ the first and second payment combined; and 3 / a price that reflects all payments received - the price of the initial transaction, plus the value per unit of coffee sold reflected in the second payment and dividend. We find that cooperatives offer significantly higher prices than other buyers, as seen in the significant positive coefficients of sales to certified and non-certified cooperatives (Table 5). We also find that certification raises the price of red cherries, on top of the cooperative effect. However, the difference of prices offered by certified and non-certified cooperatives is not significant (as measured through an F-test) in the first specification, i.e. in the case that the first payment only is used. This confirms the results that were found in Table 3. On the other hand, when the full price of red cherries is used as dependent variable, we find a price difference of certified cooperatives compared to non-certified ones, shown by the (weakly significant, at $5 \%$ in specification 2 and at $10 \%$ in specification 3 ) F-test at the bottom of Table 5 . 
Table 5-Hedonic pricing regression for red cherries at producer level, US cents per lb., 2013 harvest

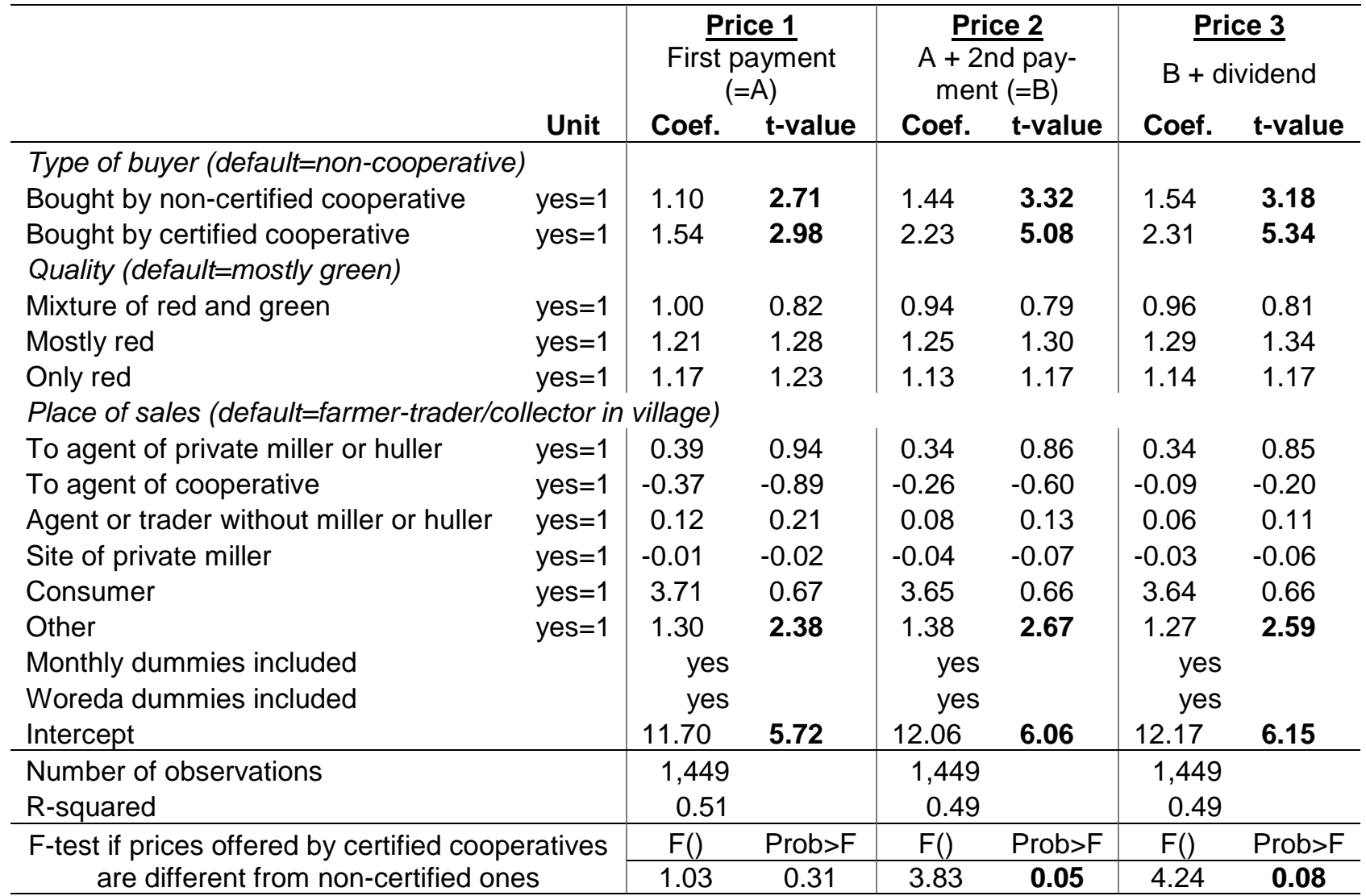

Source: Authors' calculations based on ESSP's coffee producer survey 2014

Note: Standard errors clustered at the kebele level; t-values in bold are significant at the 5 percent level.

The difference in price offered between certified and non-certified cooperatives amounts to 0.77 US cents per lb. of red cherries in the third specification. On average, six $\mathrm{kg}$ of Arabica red cherries converts to $1 \mathrm{~kg}$ of clean green coffee beans (ITC 2011). Prices of these two coffee forms can therefore be compared when a conversion factor of 6 is used. This translates to a premium of 4.6 US cents per lb. green coffee equivalent at the producer level and compares to premiums at the export level of 15.1 US cents per lb. during the years 2013-2014 (Table 1). ${ }^{21}$ Using this method, we estimate the transmission of VSS premiums to producers as being less than one-third of the premium received by exporters of VSS certified coffee.

\subsection{What explains the gap?}

The evidence presented above shows a rather small transmission of VSS premiums at the export level when comparing prices that are paid to coffee producers. It appears that two-thirds of the quality premium is not directly

\footnotetext{
${ }^{21}$ Using an exchange rate of 19.2 Birr/USD at the end of 2013 when most of the sales of red cherries took place.
} 
transmitted. This then begs the question about where most of the premium paid for VSS certification at the export level goes. A number of explanations can be forwarded.

First, VSS are implemented by primary cooperatives, organized at the village level, which are grouped in cooperative unions at zonal and regional levels. ${ }^{22}$ In the majority of the cases, primary cooperatives do not interact with international buyers, instead the cooperative unions perform the commercial transactions. To pay for the costs that the unions incur, an overhead charge of 30 percent of the quality premium is withheld in the case of Organic but not for Fair Trade-certification. The remaining 70 percent of the VSS premiums goes to the primary cooperatives. While the 30 percent allows for the payment of certification costs in some of the cooperative unions, this is not the case for all cooperatives, and the 70 percent transmitted to primary cooperatives is required to cover certification costs. These costs are usually substantial. De Janvry et al. (2014) estimate these costs to be up to 3 US cents per lb. Moreover, a rule is that 70 percent of the profits of the primary cooperatives are transferred to farmers, while the rest is kept for the functioning of the primary cooperative. In the case that a primary cooperative incurs no expenses and the complete quality premium would be considered profits, a maximum of 49 percent (70 percent of 70 percent) of the quality premium would be transmitted. ${ }^{23}$

Second, a common practice in Community-Driven Development projects, with which VSS schemes are commonly associated, is that it is up to the local community, in this case the primary cooperatives, to decide how the extra budget they receive from the VSS certification quality premiums is used (Binswanger-Mkhize et al. 2009). These funds usually are invested in communal assets, such as medical and educational facilities, that provide benefit to coffee farmers in other ways than by higher prices. It is however also possible that the quality premiums are being used for investments that may not directly benefit farmers, such as better facilities or more staff at the cooperative (Haight 2011).

Third, our interviews highlighted that parts of the quality premiums were used by some of the primary cooperatives to pay off debts. These incurred debts are sometimes high because of volatility in international prices, especially in recent years in situations where these cooperatives bought cherries at relatively high prices from farmers

\footnotetext{
${ }^{22}$ There are seven such unions in the country.

${ }^{23}$ See http://www.oromiacoffeeunion.org/
} 
and could only sell coffee beans at a low price later in the year. Some cooperatives also invested in the purchase of wet mills by taking out loans. ${ }^{24}$

\section{DO VSS CERTIFICATES ACHIEVE THEIR SUSTAINABILITY OBJECTIVES?}

In addition to economic sustainability (income) effects, VSS certificates are also designed to improve environmental, labor, and social environments (Raynolds et al. 2007; Raynolds, 2009; Potts et al. 2014; Arnould et al. 2009; Dragusanu et al. 2014; Jaffee and Howards, 2010; Mutersbaugh, 2002). We look at the extent to which these objectives are achieved by using data from the farm survey. To understand the incentives for sales to a cooperative, farmers were requested to provide details on the reasons for selling to a specific buyer for each coffee sales transaction that each farmer made. Farmers who sold to cooperatives stated that advantages associated with being a member of the cooperative was the major reason for their choice (Table 6). We also enquired about what these farmers saw as the benefits of having access to cooperatives in the community, dividing the results based on certified and non-certified ones. The results indicate that most farmers do not believe that cooperatives offer higher prices, but they state that there are other advantages linked to advice and location, as well as payments of dividends. No significant difference is noted between certified and non-certified cooperatives.

\footnotetext{
${ }^{24}$ It is also worth noting that there is frequent oversupply of certified products that cannot be sold primarily because there are not enough buyers for VSS certified products (e.g. de Janvry et al. 2014; Potts et al. 2014). As noted earlier, at the global level, 40 percent of global production in 2012 was estimated to have been produced in compliance with VSS standards, but only 15 percent of that quantity was sold under that label (Potts et al. 2014). These supplies are then sold on conventional markets. In such cases, even though farmers are certified, their coffee would not be sold at a higher price associated with VSS certification. However, in recent years, the large majority of the coffee that was sold to the cooperative unions in Ethiopia was sold under a VSS certification label. E.g. in 2012 and 2013, 75 and 72 percent respectively of all coffee export by cooperatives was sold under VSS certification.
} 


\begin{tabular}{|c|c|c|c|c|c|c|}
\hline & Unit & $\begin{array}{c}\text { Observa- } \\
\text { tions }\end{array}$ & $\begin{array}{l}\text { Non- } \\
\text { coopera- } \\
\text { tives }\end{array}$ & $\begin{array}{c}\text { Non-cer- } \\
\text { tified } \\
\text { coopera- } \\
\text { tives }\end{array}$ & $\begin{array}{c}\text { Certified } \\
\text { coopera- } \\
\text { tives }\end{array}$ & All \\
\hline \multicolumn{7}{|c|}{ Major reasons why farmer chose this buyer in 2013 red cherries' sales transaction: } \\
\hline "Gives higher price" & $\%$ yes & 282 & 22.3 & 42.9 & 11.6 & 19.5 \\
\hline "Accepts large quantities" & $\%$ yes & 5 & 0.4 & 0.0 & 0.4 & 0.4 \\
\hline "Accepts small quantities" & $\%$ yes & 30 & 3.3 & 0.0 & 0.6 & 2.1 \\
\hline "Gives advances when needed or lends money" & $\%$ yes & 32 & 3.7 & 0.0 & 0.4 & 2.2 \\
\hline "Pays immediately" & $\%$ yes & 104 & 12.2 & 1.2 & 0.7 & 7.2 \\
\hline "Is close by" & $\%$ yes & 228 & 25.5 & 11.9 & 1.8 & 15.7 \\
\hline "No real difference with other buyers" & $\%$ yes & 185 & 22.1 & 2.4 & 0.6 & 12.8 \\
\hline "Only a single buyer" & $\%$ yes & 12 & 1.4 & 0.0 & 0.2 & 0.8 \\
\hline "Trust his weighing" & $\%$ yes & 23 & 2.0 & 4.8 & 0.6 & 1.6 \\
\hline "Buyer is a relative" & $\%$ yes & 20 & 2.5 & 0.0 & 0.0 & 1.4 \\
\hline "Buys at the farm gate" & $\%$ yes & 25 & 3.1 & 0.0 & 0.0 & 1.7 \\
\hline "Buyer has the needed inputs" & $\%$ yes & 1 & 0.1 & 0.0 & 0.0 & 0.1 \\
\hline "Because of advantages of being a member" & $\%$ yes & 498 & 1.2 & 35.7 & 83.3 & 34.4 \\
\hline "Other" & $\%$ yes & 4 & 0.4 & 1.2 & 0.0 & 0.3 \\
\hline Total & $\%$ yes & 1449 & 100.0 & 100.0 & 100.0 & 100.0 \\
\hline \multicolumn{7}{|l|}{ For those having option to sell to cooperatives } \\
\hline \multicolumn{7}{|l|}{ Main advantages of selling to a cooperative: } \\
\hline "Provide higher prices" & $\%$ yes & 627 & & 49.5 & 52.1 & 50.9 \\
\hline "Provide credit" & $\%$ yes & 623 & & 25.8 & 14.4 & 19.6 \\
\hline "Provide advice" & $\%$ yes & 626 & & 44.8 & 60.9 & 53.5 \\
\hline "Provide inputs" & $\%$ yes & 627 & & 41.5 & 10.6 & 24.7 \\
\hline "Pay immediately" & $\%$ yes & 626 & & 58.0 & 22.4 & 38.7 \\
\hline "Are close by" & $\%$ yes & 627 & & 55.1 & 58.5 & 56.9 \\
\hline "Do not cheat with weights" & $\%$ yes & 619 & & 67.7 & 55.6 & 61.1 \\
\hline "Pay dividends or second payments later" & $\%$ yes & 617 & & 42.2 & 80.3 & 63.2 \\
\hline
\end{tabular}

Source: Authors' calculations based on ESSP's coffee producer survey 2014

We rely on regressions and matching techniques to assess the influence of certification on indicators other than on prices. To first understand some of the characteristics associated with the type of farmers who participate in selling certified coffee, we run a probit of certified versus non-certified farmers (Table 7). We include on the righthand side of the regression measures of household characteristics (size of household, gender of the head of household, education levels), farm characteristics (land owned), and distance to facilities. The results show that VSS-certified households are located closer to paved roads and closer to coffee cooperatives. They also show that the heads of VSS-certified households are older and more likely to have been in school. 
Table 7-Associates of participation in certification schemes

\begin{tabular}{llrr}
\hline & Unit & Coef. & z-value \\
\hline Gender of head of household & male=1 & -0.206 & -1.02 \\
Age of head of household & $\log$ (years) & 0.792 & $\mathbf{3 . 8 0}$ \\
Total land owned & $\log ($ ha) & -0.629 & $-\mathbf{3 . 7 0}$ \\
Household size & $\log$ (number) & 0.037 & 0.25 \\
Dependency ratio & share & -0.039 & -0.43 \\
Head of household completed primary school & yes=1 & -0.052 & -0.45 \\
Head of household did not go to school & yes=1 & -0.718 & $-\mathbf{- 4 . 7 3}$ \\
Travel time to all-weather road & $\log$ (minutes) & -0.062 & -1.18 \\
Travel time to cooperative that buys coffee & $\log$ (minutes) & -0.401 & $\mathbf{- 5 . 4 6}$ \\
Travel time to cooperative that distributes inputs & $\log$ (minutes) & 0.287 & $\mathbf{- 2 . 6 3}$ \\
Constant & & -2.496 & $\mathbf{- 2 . 5 8}$ \\
\hline Number of observations & & 1,118 & \\
R-squared & & 0.10 & \\
\hline
\end{tabular}

Source: Authors' calculations based on ESSP's coffee producer survey 2014

Note: Standard errors clustered at the kebele level; z-values in bold are significant at the 5 percent level.

We then attempt to understand the association of certification with a number of stated outcome variables of VSS, including adoption of better technologies, organic indicators, labor standards, and access to social services. We rely on two methods to assess association of certification, i.e. simple OLS or probit estimates (where we compare certified and non-certified cooperatives with an F-test) as well as a matching methodology, using the probit model that is presented in Table 7 to calculate propensity scores. ${ }^{25}$

First, we look at how certified farms implement improved production technologies more effectively, receive more visits from extension agents, and achieve higher yields. The results indicate that certified farmers have higher adoption rates of improved technologies (especially stumping and compost use ${ }^{26}$, which are significantly higher in

\footnotetext{
${ }^{25}$ It should be noted that matching methods assume that all relevant variables are included in the observed covariates and that there are no unobserved variables. The method also does not use observations with no suitable matches (Angrist and Pischke, 2009 p. 213-216). Caution in interpretation is therefore needed.

${ }^{26}$ Compost use is one of the extension messages propagated by the Ethiopian Ministry of Agriculture and Natural Resources to increase productivity. However, compost use is overall still relatively low as our results show that compost was only used on 9 percent of the coffee area. Minten et al. (2017) estimate that increasing the share of composted trees from 0 to 100 percent leads to an increase in coffee yield of 70 percent. However, as only dummies are used in their analysis and quantities and frequency of compost used matter and as coffee plants need different nutrients to produce well (see van der Vossen, 2005), further analysis is called for.
} 
both specifications ${ }^{27}$ ), but we also find that certified farmers do not have better access to extension agents or have higher yields (Table 8).

The second series of indicators look at the use of chemical fertilizer, pesticides, and herbicides. The use of these chemicals for coffee production is extremely low in Ethiopia and most coffee production is organic, even though farmers may not actually be organic-certified. We see that only 6 and 2 percent of the coffee farmers use chemical fertilizers and other agro-chemicals, respectively. The low level of use of inorganic chemicals might therefore explain why - except for the matching exercise for chemical fertilizer use - we do not find any significant results of the effect of certification on the use of these chemical inputs in any of the regressions or the matching exercises that were conducted.

Third, farmers were asked to indicate details on the extent that children (defined as those who were younger than 16 years of age) participated in different coffee production activities. Questions were asked on the use of child wage labor as well. A low 1.5 percent of households reported using child wage labor in coffee production activities, with no significant difference between certified and non-certified households. 30 percent of the coffee farms in our sample reported using children in coffee production activities, with child labor as a share of total labor time in the coffee production process being 6 percent. We find no significant association of VSS certification on the likelihood of using children in any of the two specifications (Table 8). On the other hand, we find that the share of children in total labor is lower on certified coffee farms in both matching exercises.

Fourth, as a number of the VSS certified cooperatives reported investments that were used towards better social services, including more and better school infrastructure, we test to what extent school attendance of schoolaged children is associated with VSS certification. ${ }^{28}$ We find that VSS-certified households are characterized by significantly higher school attendance rates as shown by statistically significant results in the matching specification (Table 8). While school attendance is higher for households that sell to VSS-certified than for households that

\footnotetext{
${ }^{27}$ Although compost use is only significant at the $10 \%$ level in the OLS specification.

${ }^{28}$ It is to be noted that school attendance rates were measured by the share of school-age children reported to be in school by the household itself at the time of the survey. There was no external verification of that statement and there was no assessment of the quality of the school nor of absenteeism of teachers and children in these schools. This is therefore a crude measurement and caution in interpretation is warranted.
} 
sell to non-certified cooperatives, in the OLS specification this difference is not statistically significant. Overall, schooling attendance rates are higher in this specification for anybody who sells to coffee cooperatives. 


\begin{tabular}{|c|c|c|c|c|c|c|c|c|c|c|c|}
\hline \multirow{3}{*}{ Dependent variable } & \multirow{3}{*}{ Unit } & \multicolumn{5}{|c|}{ Coffee production } & \multicolumn{2}{|c|}{$\begin{array}{l}\text { Organic } \\
\text { practices }\end{array}$} & \multicolumn{2}{|c|}{$\begin{array}{l}\text { Labor by } \\
\text { children }\end{array}$} & \multirow{3}{*}{$\begin{array}{c}\text { School- } \\
\text { ing }\end{array}$} \\
\hline & & Yield & $\begin{array}{l}\text { Exten- } \\
\text { sion } \\
\text { visits }\end{array}$ & $\begin{array}{l}\text { Uses } \\
\text { com- } \\
\text { post }\end{array}$ & $\begin{array}{l}\text { Adopts } \\
\text { mulch- } \\
\text { ing }\end{array}$ & $\begin{array}{l}\text { Adopts } \\
\text { stump- } \\
\text { ing }\end{array}$ & $\begin{array}{l}\text { Uses } \\
\text { chemi- } \\
\text { cal ferti- } \\
\text { lizer }\end{array}$ & $\begin{array}{l}\text { Uses } \\
\text { pesti- } \\
\text { cides or } \\
\text { herbi- } \\
\text { cides }\end{array}$ & $\begin{array}{l}\text { Uses } \\
\text { child la- } \\
\text { bor on } \\
\text { coffee } \\
\text { farm }\end{array}$ & $\begin{array}{l}\text { Child la- } \\
\text { bor as } \\
\text { share of } \\
\text { all labor } \\
\text { on farm }\end{array}$ & \\
\hline & & $\begin{array}{l}\text { Quintal } \\
\text { per ha }\end{array}$ & yes $=1$ & yes $=1$ & yes $=1$ & yes=1 & yes $=1$ & yes $=1$ & yes $=1$ & share & \\
\hline Average & & 7.44 & 0.48 & 0.24 & 0.52 & 0.23 & 0.06 & 0.02 & 0.30 & 0.06 & 0.65 \\
\hline Standard deviation & & 5.48 & & & & & & & & 0.13 & 0.34 \\
\hline \multicolumn{12}{|l|}{ OLS/Probit regressions } \\
\hline \multirow[t]{2}{*}{ Households sells to certified cooperative } & Coeff. & 0.075 & 0.015 & 0.169 & 0.016 & 0.123 & 0.006 & 0.012 & -0.006 & -0.012 & 0.121 \\
\hline & t-value & 0.18 & 0.27 & 3.24 & 0.35 & 2.48 & 0.74 & 0.66 & -0.12 & -0.86 & 3.48 \\
\hline \multirow[t]{2}{*}{ Households sells to non-certified cooperative } & Coeff. & 1.128 & 0.104 & 0.052 & 0.027 & -0.070 & 0.016 & -0.021 & -0.041 & -0.011 & 0.102 \\
\hline & t-value & 1.65 & 1.75 & 1.09 & 0.52 & -1.58 & 0.65 & -3.05 & -0.77 & -0.79 & 3.07 \\
\hline Household characteristics included & & yes & yes & yes & yes & yes & yes & yes & yes & yes & Yes \\
\hline Woreda dummy variables included & & yes & yes & yes & yes & yes & yes & yes & yes & yes & Yes \\
\hline \multirow[t]{2}{*}{ Constant } & Coeff. & 6.635 & 0.051 & 0.145 & 0.301 & -0.512 & 0.109 & 0.064 & -0.700 & -0.181 & -1.036 \\
\hline & $\mathrm{t}$-value & 2.95 & 0.23 & 0.88 & 1.51 & -2.82 & 1.51 & 0.88 & -3.76 & -3.08 & -5.96 \\
\hline Observations & & 1,410 & 1,429 & 1,429 & 1,429 & 1,429 & 1,429 & 1,429 & 1,429 & 1,419 & 1,238 \\
\hline R-squared & & 0.28 & 0.16 & 0.35 & 0.32 & 0.14 & 0.33 & 0.03 & 0.16 & 0.16 & 0.30 \\
\hline \multicolumn{12}{|c|}{ F-test if certified cooperatives are different from non-certified ones } \\
\hline F-value & & 1.99 & 1.31 & 3.02 & 0.03 & 9.16 & 0.16 & 2.83 & 0.23 & 0.00 & 0.18 \\
\hline Prob $>F$ & & 0.16 & 0.25 & 0.08 & 0.86 & 0.00 & 0.69 & 0.12 & 0.63 & 0.98 & 0.67 \\
\hline \multicolumn{12}{|l|}{ Matching } \\
\hline \multirow[t]{2}{*}{ Nearest neighbor matching } & Coeff. & 0.457 & 0.045 & 0.397 & 0.300 & 0.199 & -0.063 & -0.006 & -0.022 & -0.018 & 0.065 \\
\hline & t-value & 0.91 & 0.92 & 9.16 & 6.47 & 4.24 & -3.75 & -0.58 & -0.54 & -1.66 & 2.04 \\
\hline \multirow[t]{2}{*}{ Kernel matching } & Coeff. & 0.237 & 0.045 & 0.396 & 0.312 & 0.195 & -0.053 & -0.003 & -0.021 & -0.017 & 0.058 \\
\hline & $\mathrm{t}$-value & 0.51 & 0.92 & 9.57 & 8.86 & 4.55 & -4.55 & -0.40 & -0.57 & -1.95 & 2.05 \\
\hline Observations & & 1,100 & 1,118 & 1,118 & 1,118 & 1,118 & 1,118 & 1,118 & 1,118 & 1,109 & 954 \\
\hline
\end{tabular}

Source: Authors' calculations based on ESSP's coffee producer survey 2014

Note: Standard errors clustered at the kebele level; z-values in bold are significant at the 5 percent level. 


\section{CONCLUSIONS}

Voluntary Sustainability Standards (VSS) are rapidly taking off in global value chains. However, it is not well understood to what extent the willingness-to-pay of consumers for these VSS are transmitted to producing countries. In this paper, we look in particular at the impact of VSS certification on the coffee sector in Ethiopia using unique large-scale datasets. We find that there are statistically significant quality premiums at the export level for VSS certified coffee in Ethiopia. However, while there are significant quality premiums attached to VSS certification at the export level, we find that only one-third of the quality premium at the export level is directly transmitted to producers. Part of the quality premium for producers is used for financing communal investments. While these are shown in our study to have led to higher school enrolment rates and while certified farmers show higher levels of adoption of improved production practices, however, there is limited evidence of large-scale impacts due to these communal investments. A much larger part of the premiums is used for overheads and program management. This is an important finding as Fair Trade, which, with Organic certification, was the focus of our study, is characterized by the highest premiums among VSS schemes (Potts et al. 2014). It can be assumed that even lower benefits from other VSS certification schemes trickle down to producers.

The challenge of these types of VSS certification schemes is to ensure greater transmission of the willingness-topay by consumers into higher benefits for the smallholder producers. For example, there are substantial costs to obtaining VSS certification. As stated in the requirements, minimum wages have to be paid, child wage labor is not allowed, and environmental standards (such as access to sanitation and water) have to be respected. Each of these may lead to higher production costs. ${ }^{29}$ Moreover, sound bookkeeping and management is required from democratically elected leaders. As education levels in these production areas are generally low (in our dataset,

\footnotetext{
${ }^{29}$ It is also sometimes argued that Ethiopia might forego production because of its adherence to certified organic practices. However, even when no certification is present, few farmers use chemical fertilizer, indicating that foregone production because of adherence to certified organic practices is likely to be small.
} 
39 percent of the heads of households did not go to school at all), this is often a challenge for these coffee producing communities. ${ }^{30}$ As there are these important compliance costs with VSS certification and as benefits are relatively small, this often reduces rates of returns to adhering to VSS certification for these coffee farmers.

The limited effects on improved incomes combined with significant implementation costs might therefore not give the required incentives for rapid expansion of the adoption of VSS standards in these settings. This possibly explains the slow growth of adoption in VSS certification in the case of Africa in general and of Ethiopia in particular. While there is slow growth in Fair Trade and Organic certification in the country, the uptake of other VSS schemes has been even slower. This might also be explained by the local market set-up, i.e. the Ethiopian Commodity Exchange (ECX), as well as the smallholder nature of coffee production in Ethiopia and Africa. As Fair Trade almost exclusively deals with cooperatives and they are not required to use the ECX as a trading platform, this VSS is not affected by that requirement. However, others do not require working with cooperatives. Given that the ECX market set-up requires anonymity of the sellers, the ECX is not conducive for trade in other VSScertified coffee beans. ${ }^{31}$ Nevertheless, given the often-prohibitive high costs of certification for smallholders, the majority of coffee farmers - except the commercial farms - are unlikely to show interest.

The low transmission of the premium of VSS models to effectively benefit poor producers is a concern, especially as other development programs illustrate greater efficiency in transmitting benefits of programs towards poverty alleviation. ${ }^{32}$ Although some payments towards VSS end up in the producing countries, the findings however raise questions on the efficiency of the VSS model. As it currently stands, significant resources are required for

\footnotetext{
${ }^{30}$ While managers and bookkeepers working for cooperatives can be professionals, they are sometimes hard to find in rural areas, especially in the more remote communities, and if found, paying them relatively high salaries lead to higher implementation costs for certification, taking possible benefits away from farmers.

${ }^{31}$ A law was passed in July 2008 mandating that all coffee trade would have to go through the ECX with important implications on the functioning of the domestic coffee value chain (e.g. Meijerink et al., 2014). Producers who are exporters can bypass the ECX, as can farmer cooperatives. However, the share of these latter entities in total coffee exports has been shown to be relatively small. Kufa (2012) estimates the share of plantation coffee - covering a large part of the producers that export - in total exports at 5 percent while the share of cooperatives is also relatively low, e.g. 7 percent in 2012 (Minten et al., 2014).

${ }^{32}$ For example, in the case of the Productive Safety Net Program (PSNP), one of the biggest aid programs in Ethiopia, it was estimated that beneficiaries received 80 percent of the program funds (White and Ellis 2012)
} 
VSS certification of complete product value chains to assure the transfer of the willingness-to-pay from consumers towards sustainability and poverty alleviation. ${ }^{33}$ Moreover, while the increasingly stringent private international standards on quality and food safety have been shown to meet their objective, and even to benefit farmers (e.g. Swinnen 2007), this is seemingly easier because of the focused objective that is easy to recognize by buyers. VSS objectives on the other hand might not be that easily attainable given the broad objective of 'sustainability' and substitution possibilities in the farm household economy. For example, farmers in these settings often have diverse crop portfolios. They may be able to use sustainable production practices on their coffee plots but not on their other crops. Moreover, resources can be re-allocated within the farm from coffee to other crops, e.g. no child labor on coffee plots might mean more child labor on other plots. While coffee might have been sustainably produced and certified, it is possible that little might have changed in the aggregate at the farm, village, or country level. These drawbacks are therefore seemingly a crucial challenge for the successful future of such VSS-certification programs.

Our study further points to a number of areas for future research. First, as different certification schemes fetch different retail margins, they are likely to have, not only different wholesale prices, but different price spreads between wholesale and retail. Therefore, studying the effects of other VSS certificate schemes should be a fruitful area for future research. Second, in our datasets, there is often double certification and we are therefore unable to analyze the effects of each VSS separately. As compliance costs depend on the type of VSS certificate, this is a limitation for our study and further research on this would therefore be useful. Third, it is to be noted that according to the Fair Trade set-up, the minimum guarantee price is used as a floor price. As coffee prices have been relatively high in recent years (and minimum floor prices have not been revised for a while), it is possible that effects of this program might be different in years of low international coffee prices, suggesting a more detailed look at the impact of the 'safety net' function of Fair Trade during years of low prices. Fourth, we only look at associates of quality premiums for certification. Pursuing an estimation of causal effects of certification would require more appropriate methods and datasets.

\footnotetext{
${ }^{33}$ It could be argued that they might even exclude those farmers that it intends to benefit because of high compliance costs, as seen in the low adoption of VSS certification in smallholder coffee production in Africa (Potts et al. 2014).
} 


\section{REFERENCES}

AGP-AMDE. 2015. Coffee price analysis study. Mimeo.

Angrist, J. D., and Pischke, J.S. 2009. Mostly harmless econometrics: an empiricist's companion. Princeton: Princeton University Press.

Arnould, E.J., A. Plastina, and D. Ball. 2009. Does Fair Trade Deliver on Its Core Value Proposition? Effects on Income, Educational Attainment, and Health in Three Countries. Journal of Public Policy and Marketing 28(2): 186-201.

Bacon, C. 2005. Confronting the Coffee Crisis: Can Fair Trade, Organic, and Specialty Coffee Reduce Small-Scale Farmer Vulnerability in Northern Nicaragua? World Development 33(3): 497-511.

Bacon, C. 2010. Who decides what is fair in fair trade? The agri-environmental governance of standards, access, and price. The journal of peasant studies, 37(1), pp.111-147.

Barham, B. L. and J. G. Weber. 2012. The Economic Sustainability of Certified Coffee: Recent Evidence from Mexico and Peru. World Development 40(6): 1269-1279.

Beuchelt, T. D. and M. Zeller. 2011. Profits and Poverty: Certification's Troubled Link for Nicaragua's Organic and Fair Trade Coffee Producers. Ecological Economics 70(7): 1316-1324.

Binswanger-Mkhize, H., J.P. de Regt, and S. Spector. 2009. Scaling up Local and Community Driven Development: A Real World Guide to its Theory and Practice. World Bank, Washington DC.

Chiputwa, B., D.J. Spielman, and M. Qaim. 2105. Food Standards, Certification, and Poverty among Coffee Farmers in Uganda. World Development 66: 400-412.

Cramer, C., D. Johnston, C. Oya, and J. Sender. 2014. Fair Trade, Employment and Poverty Reduction in Ethiopia and Uganda. Report submitted to the Department for International Development (DfID), government of the United Kingdom. Fair Trade, Employment and Poverty Reduction in Ethiopia and Uganda (FTEPR) research project. London: SOAS, University of London.

CTA (Technical Centre for Agricultural and Rural Cooperation (ACP-EU)). 2013. Executive brief: Coffee Sector. Wageningen, The Netherlands: Agritrade. (http://agritrade.cta.int/Agriculture/Commodities/Coffee/Executive-Brief-Update2013-Coffee-sector, accessed 16 December 2014).

de Janvry, A., C. McIntosh, and E. Sadoulet. 2014. Fair Trade and Free Entry: Can a Disequilibrium Market Serve as a Development Tool? Mimeo. (http://irps.ucsd.edu/assets/001/505311.pdf, accessed 16 December 2014). 
Dragusanu, R., and N. Nunn. 2014. The Impacts of Fair Trade Certification: Evidence From Coffee Producers in Costa Rica. , Mimeo. (http://scholar.harvard.edu/files/nunn/files/draft_august_2013.pdf, accessed 16 December 2014).

Dragusanu, R., D. Giovannucci, D. Nunn. 2014. The Economics of Fair Trade. Journal of Economic Perspectives 28 (5): 217-236.

Eakin, H., Tucker, C. and Castellanos, E., 2006. Responding to the coffee crisis: a pilot study of farmers' adaptations in Mexico, Guatemala and Honduras. The Geographical Journal, 172(2), pp.156-171.

Elder, S.D., H. Zerriffi, and P. Le Billon. 2012. Effects of Fair Trade Certification on Social Capital: The Case of Rwandan Coffee Producers. World Development 40 (11): 2355-2367.

Giovannucci, D., and S. Ponte. 2005. Standards as a New Form of Social Contract? Sustainability Initiatives in the Coffee Industry. Food Policy 30 (3): 284-301.

Giovannucci, D., O. von Hagen, and J. Wozniak. 2014. Corporate Social Responsibility and the Role of Voluntary Sustainability Standards, in C. Schmitz-Hofman et al., eds. Voluntary Sustainability Standards, Natural Resource Management in Transition 1, Berlin and Heidelberg: Springer-Verlag.

Haight, C. 2011. The Problem with Fair Trade Coffee. Stanford Social Innovation Review. Summer 2011 edition. (http://www.ssireview.org/articles/entry/the_problem_with_fair_trade_coffee, accessed 16 December 2014).

Henson, S., and T. Reardon. 2005. Private Agri-Food Standards: Implications for Food Policy and the Agri-Food System. Food Policy 30: 241-253.

Hoebink, P., R. Ruben, W. Elbers, and B. Van Rijsbergen. 2014. The Impact of Coffee Certification on Smallholder Farmers in Kenya, Uganda and Ethiopia. Report prepared by Centre for International Development Issues Nijmegen (CIDIN). Nijmegen, The Netherlands: Radboud University.

ITC (International Trade Centre). 2011. The Coffee Exporters Guide. Geneva: ITC.

Jaffee, D. and Howard, P.H., 2010. Corporate cooptation of organic and Fair Trade standards. Agriculture and Human Values, 27(4), pp.387-399.

Jaffee, D., 2014. Brewing justice: Fair trade coffee, sustainability, and survival. University of California Press.

Jena, P.R., B.B. Chichaibelu, T. Stellmacher, and U. Grote. 2012. The Impact of Coffee Certification on Smallscale Producers' Livelihoods: A Case Study from the Jimma Zone, Ethiopia. Agricultural Economics 43 (4): 429-440. 
Johannessen, S. and H. Wilhite. 2010. Who Really Benefits from Fair Trade? An Analysis of Value Distribution in Fair Trade Coffee. Globalizations 7(4), 525-544.

Kersting, S., and M. Wollni. 2012. New Institutional Arrangements and Standard Adoption: Evidence from Small-scale Fruit and Vegetable Farmers in Thailand. Food Policy 37 (4): 452-462.

Kilian B, C. Jones, L. Pratt, and A. Villalobos. 2006. Is Sustainable Agriculture a Viable Strategy to Improve Farm Income in Central America? A Case Study on Coffee. Journal of Business Research 59(3), 322-330.

Kodama, Y. 2009. The Effects of Fair Trade on Coffee Producers: A Case Study of Ethiopian Coffee Cooperatives. 16th International Conference of Ethiopian Studies. 297-299.

Kufa, T. 2012. Recent coffee research development in Ethiopia. Presentation at the "Ethiopian Coffee Export Conference: Strengthening the Legacy of Our Coffee", November 8-9, 2012, Hilton, Addis Ababa

Lancaster, K. 1966. New Approach to Consumer Theory. Journal of Political Economy 74 (2): 132-157.

Langen, N., Adenauer L. 2013. Where does the Fair Trade price premium go? Confronting consumers' request with reality. Social Enterprise Journal 9(3): $293-314$.

Meijerink, G., E. Bulte, and D. Alemu. 2014. Formal institutions and social capital in value chains: The case of the Ethiopian Commodity Exchange. Food Policy, 49: 1-12.

Mendoza, R. and Bastiaensen, J. 2003. Fair trade and the coffee crisis in the Nicaraguan Segovias. Small Enterprise Development 14(2): 36-46.

Minten, B., Randrianarison, L., and Swinnen, J. 2009. Global retail chains and poor farmers: Evidence from Madagascar. World Development 37(11): 1728-1741

Minten, B., S. Tamru, T. Kuma, and Y. Nyarko. 2014. Structure and Performance of Ethiopia's Coffee Export Sector. Ethiopia Strategy Support Program (ESSP) Working Paper 66. Addis Ababa: International Food Policy Research Institute.

Minten, B., Dereje, M., Engida, E., Kuma, T. 2017. Coffee value chains on the move: Evidence from Ethiopia. Food Policy, forthcoming.

Mutersbaugh, T., 2002. The number is the beast: a political economy of organic-coffee certification and producer unionism. Environment and Planning A, 34(7), pp.1165-1184.

Panhuysen, S., and J. Pierrot. 2014. Coffee Barometer 2014. The Hague, The Netherlands: HIVOS. 
Pierrot, J., D. Giovannucci, and A. Kasterine. 2011. Trends in the Trade of Certified Coffee. Geneva: International Trade Center.

Potts, J., M. Lynch, A. Wilkings, G. Huppé, M. Cunningham, and V. Voora, 2014. The State of Sustainability Initiatives Review 2014. London: International Institute for Sustainable Development and the International Institute for Environment and Development.

Raynolds, L., D. Murray, and A. Heller. 2007. Regulating Sustainability in the Coffee Sector: A Comparative Analysis of Third-party Environmental and Social Certification Initiatives. Agriculture and Human Values 24 (2): 147-163.

Raynolds, L.T., 2009. Mainstreaming fair trade coffee: From partnership to traceability. World development, 37(6), pp.10831093.

Reardon, T., C. B. Barrett, J. Berdegué, and J. Swinnen. 2009. Agrifood Industry Transformation and Small Farmers in Developing Countries. World Development 37 (11): 1717-1727.

Ruben, R., and R. Fort. 2012. The Impact of Fair Trade Certification for Coffee Farmers in Peru. World Development 40 (3): 570-582.

Rueda, X., and E.F. Lambin. 2012. Linking Globalization to Local Land Uses: How Eco-consumers and Gourmands are Changing the Colombian Coffee Landscapes. World Development 41: 286-301

Rueda, X., and E.F. Lambin. 2013. Responding to Globalization: Impacts of Certification on Colombian Small-scale Coffee Growers. Ecology and Society 18 (3): 21.

Stellmacher, T., and U. Grote. 2011. Forest Coffee Certification in Ethiopia: Economic Boon or Ecological Bane?. Working Paper Series 76, Centrum for Development Research, University of Bonn

Swinnen, J., ed. 2007. Global supply chains, standards and the poor: How the globalization of food systems and standards affects rural development and poverty. Wallingford, UK: CAB International.

Valkila, J., and A. Nygren. 2009. Impacts of Fair Trade Certification on Coffee Farmers, Cooperatives, and Laborers in Nicaragua. Agriculture and Human Values 27 (3): 321-333.

Valkila, J., Haaparanta, P. and Niemi, N., 2010. Empowering coffee traders? The coffee value chain from Nicaraguan Fair Trade farmers to Finnish consumers. Journal of Business Ethics, 97(2), pp.257-270.

Van der Vossen, H.A.M., 2005. A critical analysis of the agronomic and economic sustainability of organic coffee production. Experimental agriculture, 41(04), pp.449-473. 
Wang, H., X. Dong, S. Rozelle, J. Huang, T. Reardon. 2009. Producing and Procuring Horticulture Crops with Chinese Characteristics: The Case of Northern China. World Development 37 (11): 1791-1801.

Weber, J. G. 2011. How Much More do Growers Receive for Fair Trade-Organic Coffee? Food Policy 36 (5): 678-685.

White, P., and F. Ellis. 2012. Ethiopia's Productive Safety Net Program, 2010 - 2014 - A value for money assessment. DFID/International Development UEA.

Wollni, M., and M. Zeller. 2007. Do Farmers Benefit from Participating in Specialty Markets and Cooperatives? The Case of Coffee Marketing in Costa Rica. Agricultural Economics 37 (2): 243-248. 